\title{
CEBPE wt Allele
}

National Cancer Institute

\section{Source}

National Cancer Institute. CEBPE wt Allele. NCI Thesaurus. Code C52527.

Human CEBPE wild-type allele is located in the vicinity of $14 q 11.2$ and is approximately 2 $\mathrm{kb}$ in length. This allele, which encodes CCAAT/enhancer-binding protein epsilon, plays a role in transcriptional promotion. Mutant alleles are associated with specific granule deficiency. 